\title{
Next-generation cancer genomics
}

\author{
Elaine R Mardis ${ }^{*}$, The Washington University Cancer Genome Initiative project team \\ From Beyond the Genome: The true gene count, human evolution and disease genomics \\ Boston, MA, USA. 11-13 October 2010
}

The combined discovery power of next-generation sequencing instruments and the associated somatic variation discovery of bioinformatics, applied to clinically characterized cancer samples, is changing our understanding of this disease. Since the 1930s, scientists have considered cancer a disease of the genome after observing novel chromosomal structures upon cytogenetic examination of tumor nuclei. As the resolution and sensitivity of methods for genomic examination have now permitted a nucleotide-level view of cancer genomes, we have the capability to understand somatic variation at unprecedented detail. Central to this capability is the human reference genome sequence and its annotation, which are ever improving. During the past year, our laboratory has undertaken a Cancer Genome Initiative that has produced data and analysis of 150 cancer cases (300 matched tumor and normal genomes), focusing primarily on acute myeloid leukemia, breast and lung cancers. My presentation will describe our results todate and some technical advances developed during this project.

Published: 11 October 2010
Submit your next manuscript to BioMed Central and take full advantage of:

- Convenient online submission

- Thorough peer review

- No space constraints or color figure charges

- Immediate publication on acceptance

- Inclusion in PubMed, CAS, Scopus and Google Scholar

- Research which is freely available for redistribution

Submit your manuscript at www.biomedcentral.com/submit 